\title{
Study of Using Paper Filter Whatman no.42 for Measuring Water Retention in Cement Paste
}

\author{
Dora Melati Nurita Sandi ${ }^{1}$, Indarto ${ }^{1}$, Ridho Bayuaji ${ }^{1}$, and Januarti Jaya Ekaputri ${ }^{1}$
}

\begin{abstract}
This paper is study about using paper filter Whatman no.42 for measuring water retention on cement paste. The research is conducted as experiment in laboratory by making two types of specimens. The first speciment is cement paste with variation of water cement ratio and the second one is foam cement paste. There are two step for measuring water retention on cement paste. The first step is specimen immersed with immersion duration $\left(t_{1}\right)$. The second step is searching of filter paper weight to obtain water content after contact with two specimen. $t_{1}$ is time of consistency water content on specimens. The parameters $\left(t_{1}\right)$ must be searched before measuring water retention. The result of measurement water retention be shown in a curve.
\end{abstract}

Keywords — water retention, filter paper, porosity, cement paste.

Abstrak-Penelitian ini merupakan studi tentang menggunakan kertas saring Whatman No.42 untuk mengukur retensi air pada pasta semen. Penelitian ini dilakukan sebagai percobaan di laboratorium dengan membuat dua jenis spesimen. Spesimen pertama adalah pasta semen dengan variasi rasio air semen dan yang kedua adalah pasta busa semen. Ada dua langkah untuk mengukur retensi air pada pasta semen. Langkah pertama adalah spesimen direndam dengan durasi perendaman $\left(t_{1}\right)$. Langkah kedua adalah mencari berat kertas saring untuk mendapatkan kadar air setelah kontak dengan dua spesimen. tladalah waktu konsistensi kadar air pada spesimen. Parameter $\left(t_{1}\right)$ harus dicari sebelum mengukur retensi air. Hasil pengukuran retensi air ditampilkan dalam kurva.

Kata Kunci_retensi air, kertas saring, porositas, pasta semen.

\section{INTRODUCTION}

$\mathrm{E}$ ntering of water and water penetration in concrete can be explained with two approach. They are permeability theory and water retention theory. Theory of water retention in the soil is called by suction. Many methods for measuring soil suction, one of them is the filter paper method. Filter paper method in the soil be used for concrete aims to get a measure of water retention with a simple and economical.

The first measurement suction or water retention with used paper filter method be suggested by Gardner et al., 1937. Fawcett et al., 1967 and George et al., 1967, Mc Queen et al., 1968 and Miller et al., 1968, Al-Khafaf et al., 1974 and hanks et al., 1974 [1] in the soil science discipline and has since been used primarily in soil science and agronomy. Geotechnical engineering also used filter paper method that was developed by Ho et al., 1979, Tang et al., 1979, McKeen et al., 1981, Khan et al., 1981, Ching and Fredlund et al., 1984, Gallen et al., 1985, McKeen et al., 1985, Chandler and Gutierrez et al., 1986. Simplify use paper filter with paper filter of Whatman no 42. The calibration with use filter paper of Whatman no 42 conducted by Fawcett et al., 1967 and George et al., 1967, Zerhouni et al., 1991[2] commit on wetting groove, Parcevoux et al., 1980[3] and Indarto et al., 1991 commit calibration for the same paper filter but to drying groove. The filter paper method also used in experience for the studies of airport pavement subgrade and swelling of expansive soil by Mc Keen et al., 1985

Schneider et al., 2012[4] finalize research about inverse modelling to determining hydraulic properties of

${ }^{1}$ Dora Melati Nurita Sandi, Indarto, Ridho Bayuaji, and Januarti Jaya Ekaputri are with Departement of Civil Engineering, Faculty of Civil Engineering and Planning, Institut Teknologi Sepuluh Nopember, Surabaya, 60111, Indonesia. E-mail: indarto@yahoo.co.id; a3ridho@gmail.com; januartije@gmail.com. concrete and mortar. There are two part for the research. In the first part, estimating parameters of Van Genuchten water retention curve based on experimental moisture relation data include both wetting and drying. In the second part, capillary absorption experiment were performed to numerical simulations. To obtain data of experimental water retention, estimating parameters from the calibration of Van Genuchten model. Figure 1 presents water retention curve. The result of fitted van Genuchten parameters for the wetting curve, it will be used to define parameter ranges. It be used by on genetic algorithm for based of inverse modelling. Modelling approach use HYDRUS software pocket.

This paper present that study of using paper filter Whatman no. 42 for measuring water retention in cement paste. The research is conducted as experiment in D3 civil engineering ITS laboratory. The experiment use modelling specimens with two types. They are cement paste with variation water cement ratio value and foam cement paste. Value of water cement ratio be used by $0.5,0.45,0.35$ and 0.3 . Destination of modelling specimen cement paste with variation water cement ratio and foam cement paste is to obtain different of porosity. The specimen can be tested after 28 days curing. The experiment is measuring water retention on cement paste and foam cement paste with using paper filter Whatman no. 42 to obtain water retention curve. Before measurement water retention, previously testing to determine parameter time of consistency water content on specimen $\left(\mathrm{t}_{1}\right)$.

\section{METHOD}

\section{A. Making specimen}

The specimen consist of cement paste with variation water cement ratio, and foam cement paste. The size of specimen is $5 \times 5 \times 5 \mathrm{~cm}$. The specimen for foam cement paste consist of cement paste and foam with a mixed 
composition 1:40, where 1 is a foam composition and 40 are water and cement composition or $2.5 \%$ of the volume both water and cement.

\section{B. Searching parameter for measurement water retention}

Parameter which be used for measurement water retention is time of consistency water content on specimen (t1). the specimen must was submerged by water in length of time varies. The specimen was submerged by water until obtain time of specimen saturated.

\section{Measurement water retention}

Method of measurement water retention based on ASTM D5298-19[5]. The First step is specimen immersed with immersion duration (t1). The second step search of dry filter paper weight, then insert filter paper in between two of the specimen, the specimen surface in a dry state. After filter paper contact with specimen, be searched of filter paper weight to obtain water content. Value of water retention can be obtain from water content data which were plotted on ASTM D5298-19 calibration graph and calibration filter paper method of some author, source Indarto (1991) and Indarto (2012).

\section{Porosity test}

Porosity testing based on ASTM C642 - 90[6]. Porosity value of specimen can be obtained from calculation with formula based on ASTM C 642 - 90and using some parameters. Previously, must do testing to get parameters. The first step of testing is the specimen placed in a vacuum device for 24 hour with temperature 23 degree. The second step is the water laid in tube of vacuum device until the specimen submerged by water for 6 hour. The next step is measurement of specimen weight on condition of air pressure and weight of specimens on condition of water pressure. To obtain weight of dry specimen, the specimen is placed on oven for 24 hour with temperature $1050 \mathrm{C}$.

\section{E. Ultrasonic Pulse Velocity (UPV) test}

UPV testing based on ASTM C597-97 [7], in which the UPV test works in principle to transform wave of energy electricity generated by a pulse generator sender transducer or transmitter (T) into mechanical energy waves which then propagate to the concrete. After arriving at the receiving transducer or receiver $(\mathrm{R})$, wave energy is converted back into electrical energy wave then pass through amplifier, then displayed in units of travel time.

\section{RESULTS AND DISCUSSION}

\section{A. Water retention}

\section{1) Specimen of cement paste with water cement ratio 0.5}

The Water content data was plotted on calibration graph ASTM D5298-10 and water retention curve by Fawcett, Collis George (1967), Zerhounni (1991) in wet testing. Value water retention be obtained in the form of potential of free energy (PF) and Kpa. The Value water retention was calibrated to obtain pressure head. Water content data and pressure head data was plotted in graph which be shown in figure 2 .
Graph of testing water retention in the specimen cement paste w/c 0.5 forms groove similar to the results of testing water retention in the soil which it was conducted by Hillel (1998), Zhan and Ng (2004) for two different types of soil and similar to the result of testing water retention for glass beads which it was conducted by Indarto (1991). It also shows the flow pattern similar to the graph Van Genuchten water retention for concrete and mortar. Showed in figure 3.

Type of curve characteristic water retention on cement paste, in general looked identic with the curve of glass beads, but little different with soils. Comparing water retention curve on material concrete with Van Genuchten water retention curve on concrete C-15 and mortar M-1 shows in figure 4.

Comparing water retention curve on material concrete with Van Genuchten water retention curve on concrete C-15 and mortar M-1, there are different type of characteristic. Water content on cement paste is higher than concrete $\mathrm{C}-15$ and mortar $\mathrm{M}-1$, because the material of concrete and mortar of Van Genuchten is completely different with the material tested. The concrete material of Van Genuchten consist of calcium carbonate, calcareous aggregates and superplasticizer, whereas the mortar is a mix of silica fume, limestone, and superplasticizer. So that the porosity of material tested is higher than material of Van genuchten. This is why the concrete and mortar material of Van Genuchten couldn't reach the water content higher than material tested. But in general, the water retention measured on cement paste by filter paper is feasible to use.

\section{2) Specimen of cement paste with water cement ratio 0.45}

Water content data and pressure head data was plotted in graph which be shown in figure 5 .

Curve of testing water retention in specimens of cement paste w/c 0.45 forms grooves that are not much different than the water retention in specimens of cement paste w/c 0.5. The specimen of cement paste w/c 0.45 having water content value is lower than the cement paste w/c 0.5. In the cement paste with w/c 0.5, maximum water

content value is 0.744094 and the pressure head is $5.2203 \mathrm{~m}$. While the cement paste with water cement ratio 0.45 , value is 0.647059 for water content and $9.5391 \mathrm{~m}$ for pressure head. It can be concluded from these data that with water content is high value so small water retention.

3) Specimen of cement paste with water cement ratio 0.35

Water content data and pressure head data was plotted in graph which be shown in figure 6. Curve of testing water retention in specimens of cement paste w/c 0.35 forms groove that are not much different than the water retention in specimens of cement paste with w/c 0.5 and 0.45 . The specimen of cement paste w/c 0.35 having water content value is lower than the cement paste w/c 0.5 and 0.45 . In the cement paste w/c 0.5 , maximum water content values is 0.744094 and the pressure head is $5.2203 \mathrm{~m}$. While the cement paste w/c 0.45 , value is 0.647059 for water content and $9.5391 \mathrm{~m}$ for pressure head. For the specimen of cement paste w/c 0.35 is 0.501901 for water content and 28.6733 for pressure head. 


\section{4) Specimen of cement paste with water cement ratio 0.3}

Water content data and pressure head data was plotted in graph which be shown in figure 7 . Curve of testing water retention in specimens of cement paste w/c 0.3 forms grooves that are not much different than the water retention in specimens of cement paste w/c 0.5, 0.45 and 0.35 . The specimen of cement paste w/c 0.3 having water content value is lowest than the cement paste w/c 0.5 , 0.45 and 0.35 . In the cement paste w/c 0.5, maximum water content values is 0.744094 and $5.2203 \mathrm{~m}$ for pressure head. While the cement paste with water cement ratio 0.45 , value is 0.647059 for water content and $9.5391 \mathrm{~m}$ for pressure head. For the specimen of cement paste with water cement ratio 0.35 is 0.501901 for water content and 28.6733 for pressure head. The value of water content maximum for cement paste w/c 0.3 is 0.478431 and $34.4425 \mathrm{~m}$ for head pressure value. From these data and figure 6 , it can be concluded that water content is high value so small pressure head and water retention.

\section{5) Specimen of foam cement paste}

Water content data and pressure head data was plotted in graph which be shown in figure 8.Figure 8 show water retention curve in foam cement paste. The groove in water retention curve of foam cement paste is not different then water retention curve in specimens of cement paste with variation value w/c. In specimen of foam cement paste has water content is highest than cement paste with variation value w/c. The water content value in foam cement paste is 0.780488 and $4.2787 \mathrm{~m}$ for pressure head.

Water retention curve in foam cement paste also showing groove pattern is same with Van genuchten water retention curve.

Results of testing the water retention in the test specimen foam cement paste and the specimen cement paste with the w/c variation when plotted in a graph, show the same pattern of grooves. The pattern of the grooves have a maximum water content of different. Where the maximum water content seen in sequence from largest to smallest, the foam cement paste, cement paste w/c 0.5, and cement paste w/c 0.3. The graph is presented in the figure below 9 .

\section{B. Porosity}

Porosity is the ratio of void volume in the solid with solid volume. Porosity testing based on ASTM C 642-90. Porosity testing was conducted to determine porosity values at each test specimen and to determine whether the water content correlated porosity.

Data of water content and porosity, using excel be searched for regression analysis and correlation. Where regression analysis used in statistical analysis to find the relationship between two or more quantitative variables so that one variable can be predicted from the other variables. While the correlation is used to measure the closeness of the linear relationship of two variables. Regression analysis is presented in the figure below 10 .

The regression equation obtained is $\mathrm{y}=1.137 \mathrm{x}+$ 0.075 , where $y$ is the coefficient of bound and influenced by the value of $x$. In this case $y$ is the number of pores and $x$ is the water content. The relationship between the two variables belonging to a close relationship or have a causal relationship, where the value of $\mathrm{R} 2=0.940$ and worth close to 1 , which means the direction positive unidirectional relationship. It can be concluded that the large water content indicates a large porosity.

\section{Correlation result of porosity test with result of ultrasonic pulse velocity test}

In this study, the data were obtained from the testing of porosity and UPV, searched linear regression and correlation, to determine the relationship between porosity with the speed of ultrasonic waves that propagate in concrete. The following table is a porosity test result data by UPV test results on the test specimen foam cement paste and cement paste variation water cement.

At table 2 it appears that for porosity values sequentially from the largest to smallest is the foam cement paste, cement paste w/c 0.5 , cement paste w/c 0.45 , cement paste $\mathrm{w} / \mathrm{c} 0.35$ and cement paste w/c 0.3 . However, the opposite applies for the pulse velocity. In specimens with large porosity, the UPV test results show that a small pulse velocity. Below is a graph of correlation with the UPV porosity in the test specimen foam cement paste and cement paste variation in the water cement ratio.

The regression equation obtained $y=-0.168 x+0.748$, where $y$ is the coefficient of bound and influenced by the value of $\mathrm{x}$. The variable $\mathrm{x}$ is the independent variable. In this case, the variable $\mathrm{y}$ is the porosity and $\mathrm{x}$ is the wave speed in $\mathrm{km} / \mathrm{sec}$. The relationship between the two variables have a causal relationship, where the value of $\mathrm{R}^{2}=0.826$ close to 1 and the direction to do the opposite direction, which means that a large wave velocity generated by a small porosity.

\section{CONCLUSION}

Based on test results of water retention measurements using Whatman filter paper No. 42 in specimens of cement paste, it can be concluded that:

1. This experiments show that filter paper method Whatman no 42 can be used to measure water rentention concrete material.

2. The water retention curve that resulted from testing of the cement paste, show identical with the water retention curve in the glass beads, concrete and mortar, but little different with soil.

The relationship between water retention and water content depend on porositycharacteristic of materials

\section{REFERENCES}

[1] Delwyn G. Fredlund and Hendry Rahardjo, Soil Mechanics for Unsaturated Soils, John Wiley \& Sons, Ed. INC: A wileyInterscience Publication, 1993.

[2] D G Fredlund, The implementation of unsaturated soil mechanics into geotechnical engineering, R.M. Hardy Address, Ed. Saskatoon, Canada: NRC Research Press website, 2000

[3] Charles Wang Wai Ng and Bruce Menzies, Advanced Unsaturated Soil Mechanics and Engineering. 2 Park Square, Milton Park, Abingdon, Oxon OX14 4RN, USA, 2007.

[4] Sébastien Schneider, Dirk Mallants, and Diederik Jacques, "Determining hydraulic properties of concrete and mortar by inverse modelling," in Proc. Vol. 1475 @ 2012 Materials Research Society, 2012, p. 10.1557/opl.2012601.

[5] ASTM D 5298-19. Standard Test Method for Measurement of Soi Potential (Suction) Using Filter Paper.

[6] ASTM C 642 - 90. Standard Test Method for Specific Gravity, 
Absorption, and Voids in Hardened Concrete.

[7] ASTM C597-97. Standard Test Method for Pulse Velocity Through Concrete.

[8] Indarto , "Comportement des sols soumis a une pression interstitielle negative application aux," Laboratoire de mecanique sols structures et materiaux, Ecole Centrale Paris, These. Grade De

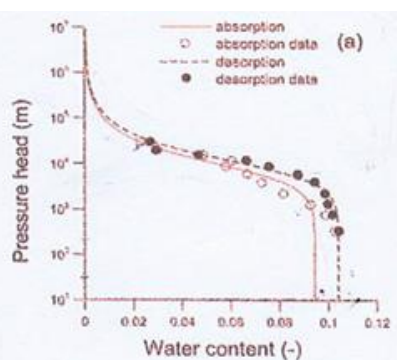

Figure 1. Water retention curves for concrete C-15-A (a) and mortar M1 (b). Source: Schneider (2012)

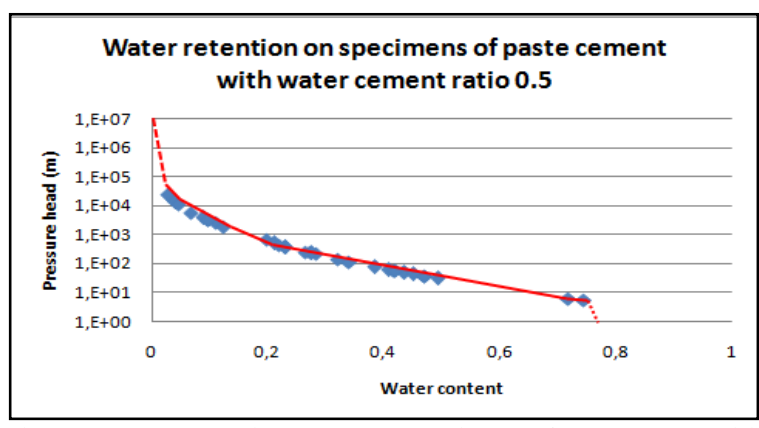

Figure 2. Water retention curves on specimens of cement paste with water cement ratio 0.5

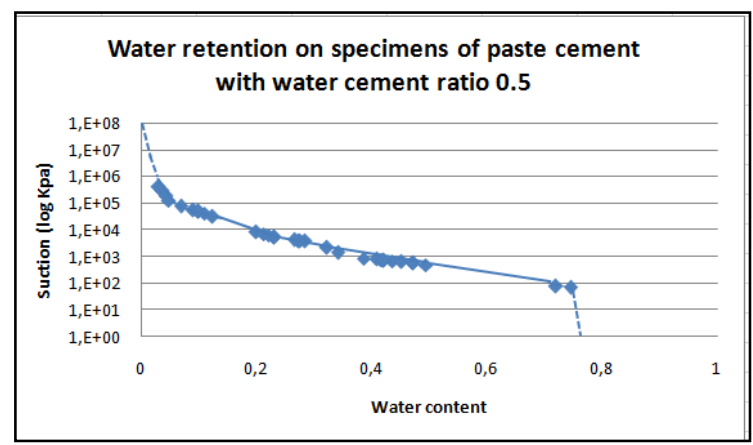

(a)

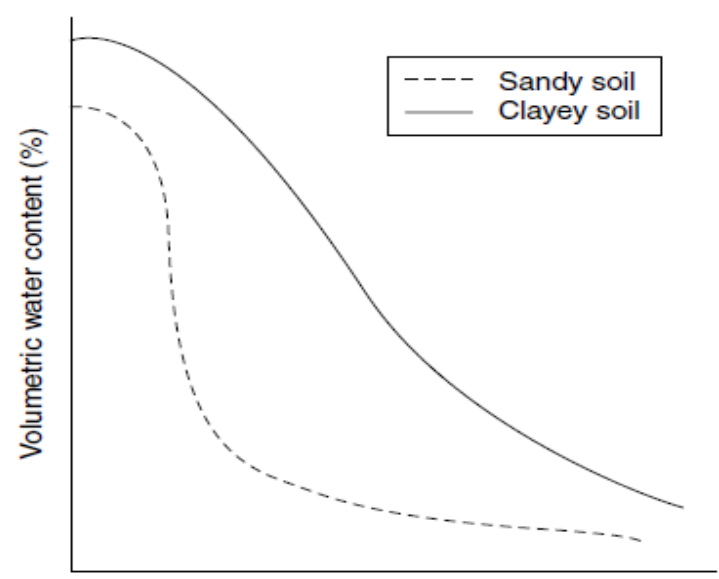

Matric suction (log kPa)

(b)
Docteur 1991.

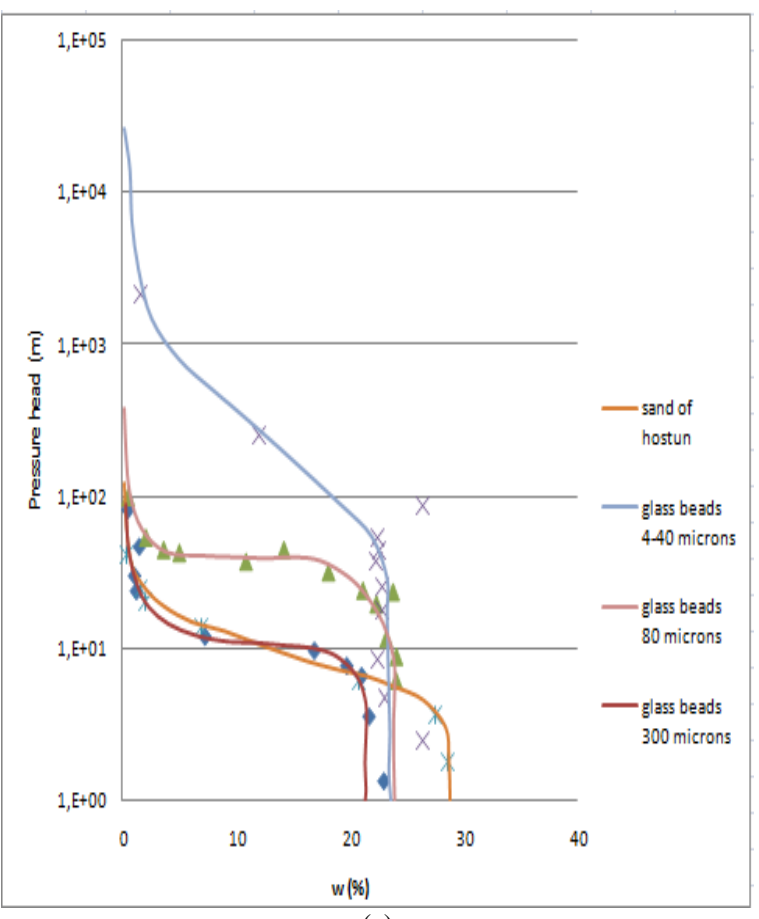

(c)

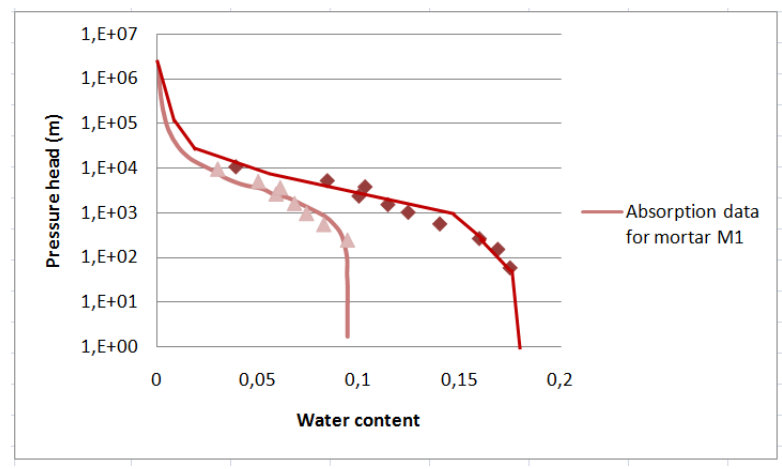

(d)

Figure 3. Water retention curves on specimens of cement paste with water cement ratio 0.5 (a) on sandy soil and clayey soil by Hillel (1998), Zhan and Ng (2004) (b) on glass beads by Indarto (1991) [8] (c) on concrete and mortar by Van Genuchten (2012)(d)

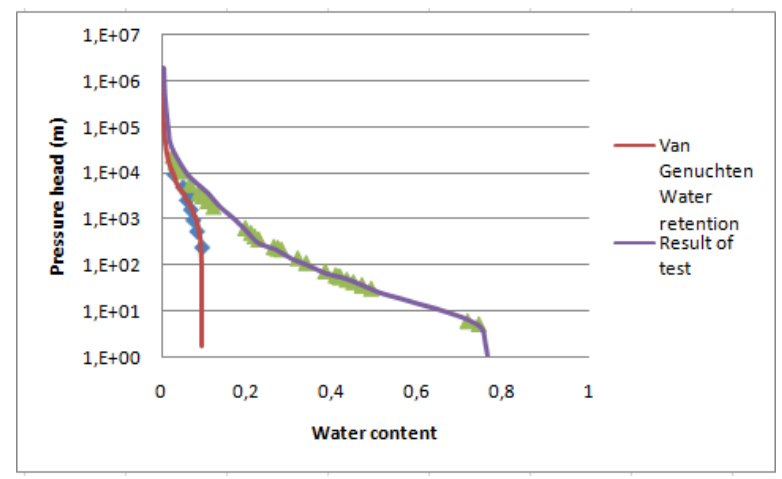

(a) 


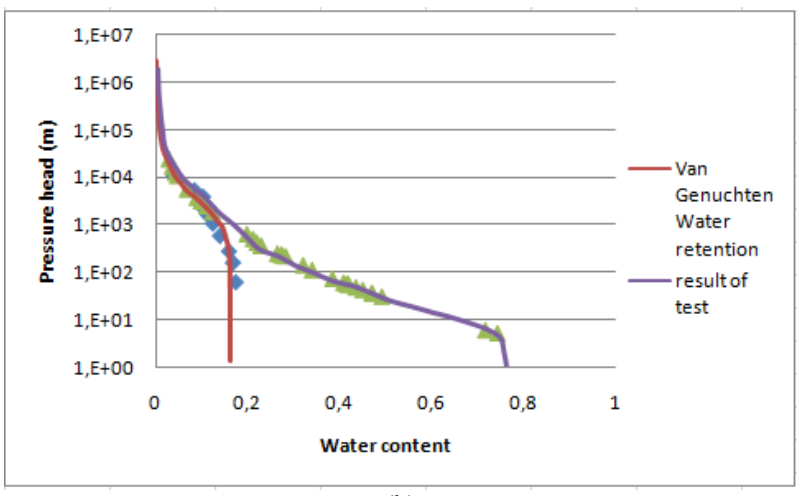

(b)

Figure 4. Comparison of water retention curves on cement paste specimens with water cement ratio 0.5 and (a) Van Genuchten water retention curve on concrete $\mathrm{C}-15$ based on absorption groove (b) Van Genuchten water retention curve on mortar M-1 on absorption groove

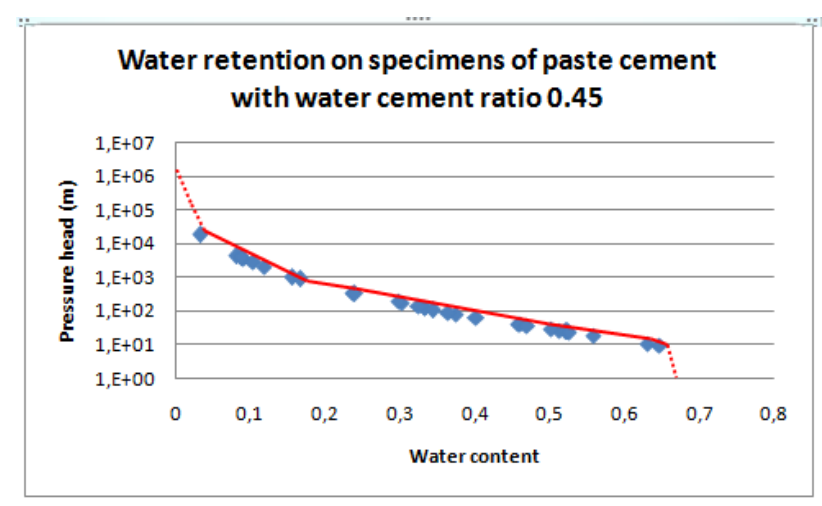

(a)

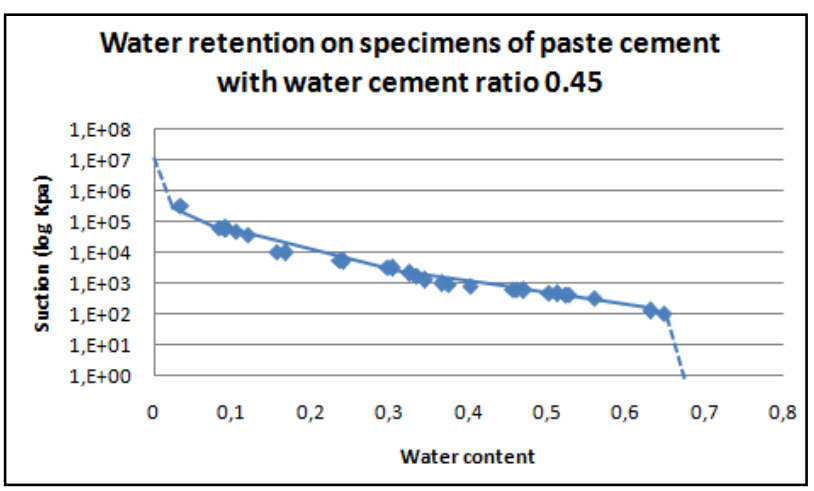

(b)

Figure 5. Water retention curves on specimens of cement paste with water cement ratio 0.45 (a) in log metre (b) in log Kpa

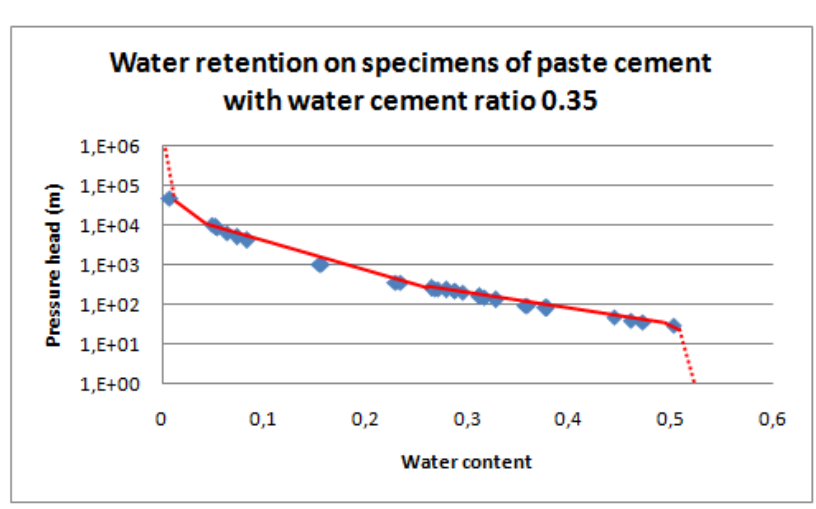

(a)

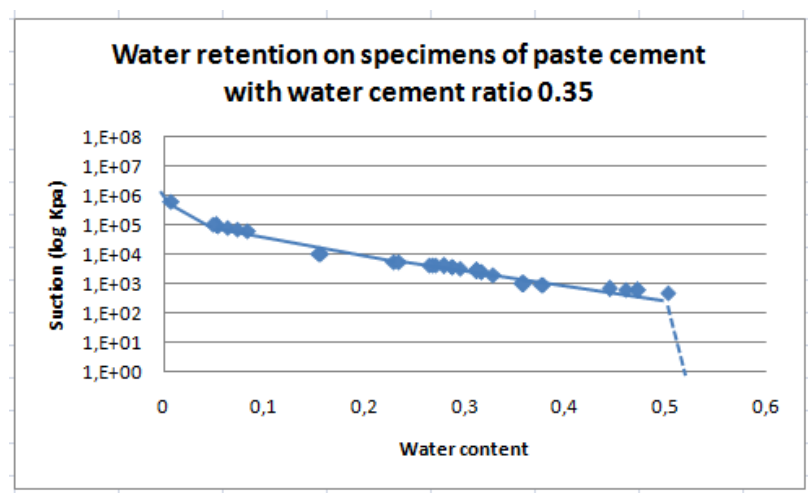

(b)

Figure 6. Water retention curves on specimens of cement paste with water cement ratio 0.35 (a) in log metre (b) in $\log \mathrm{Kpa}$

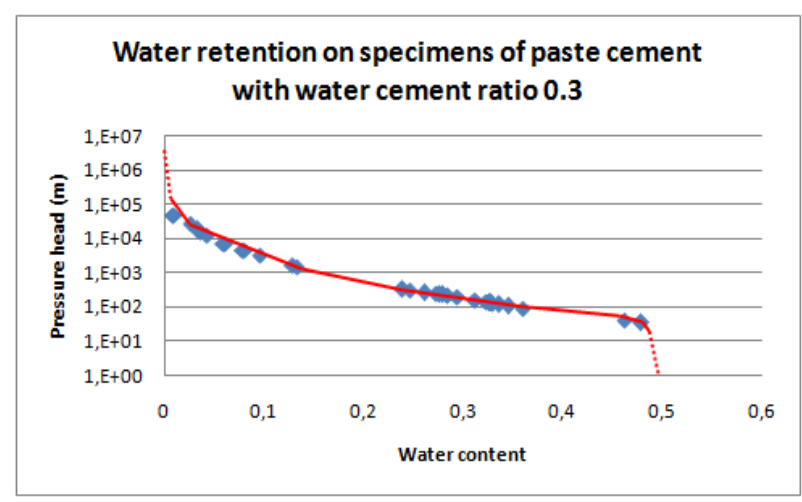

(a)

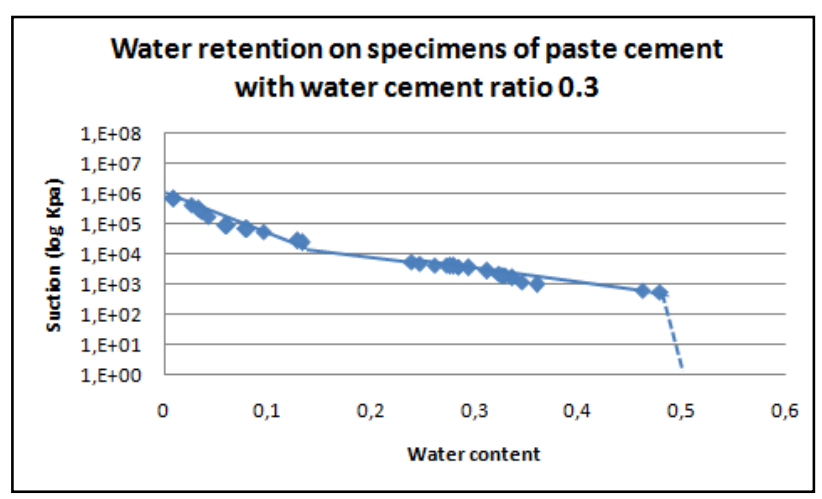

(b)

Figure 7. Water retention curve on specimens of cement paste with water cement ratio 0.3 (a) in log metre (b) in log Kpa

Water retention specimens of paste cement foam

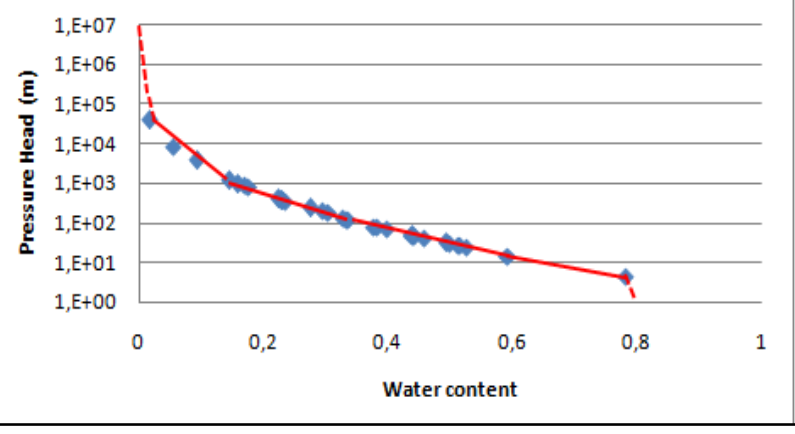

(a) 


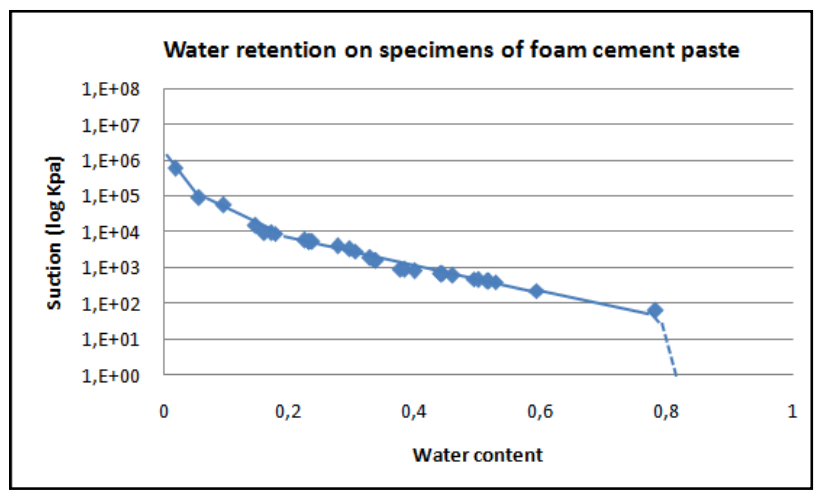

(b)

Figure 8. Water retention curve in specimens of foam cement paste (a) in log metre (b) in $\log \mathrm{Kpa}$

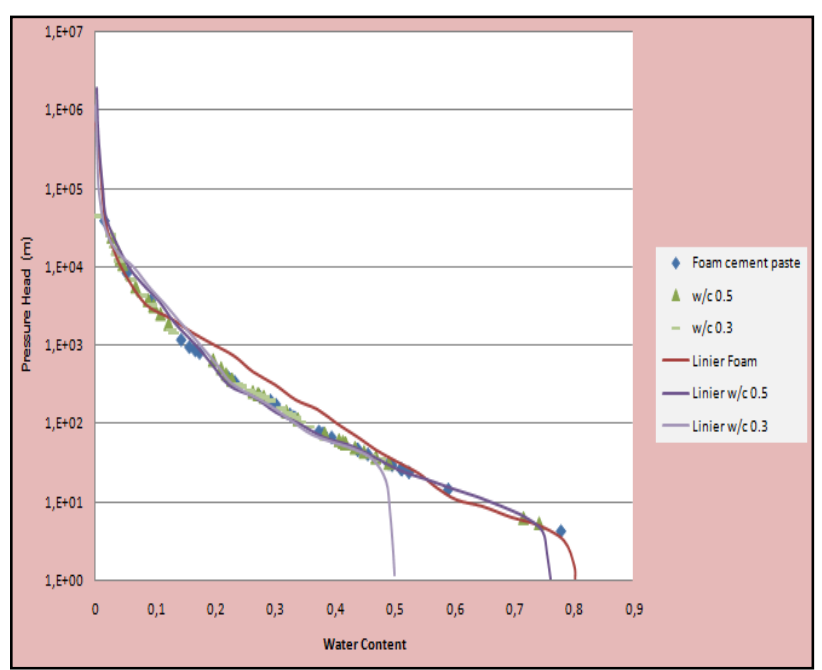

Figure 9. Water retention curves on specimens of cement paste with variation water cement ratio and foam cement paste

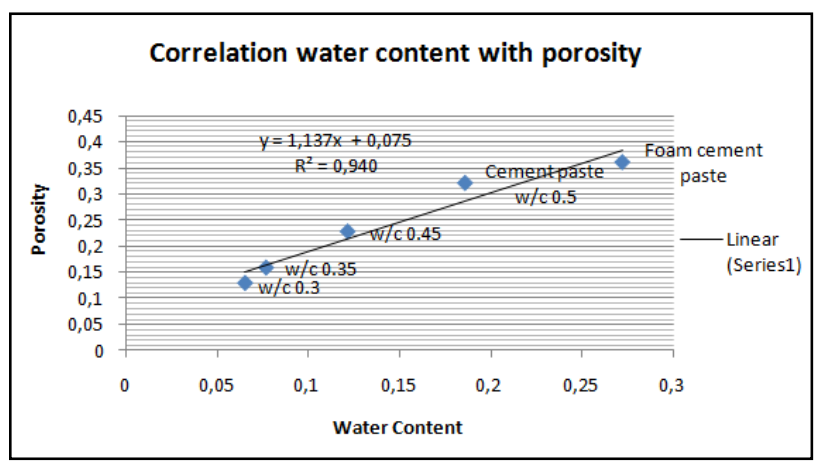

Figure 10. Correlation water content with porosity in specimen of foam cement paste and cement paste with variation water cement ratio

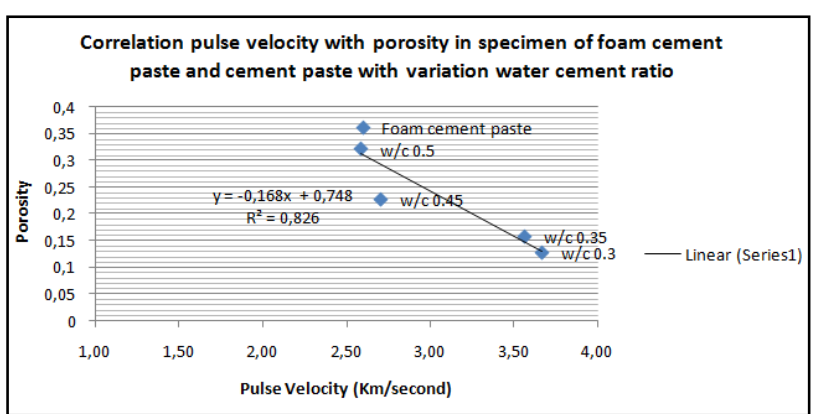

Figure 11. Correlation pulse velocity with porosity in specimen of foam cement paste and cement paste with variation water cement ratio

TABLE 1.

DATA OF RESULT POROSITY TEST

\begin{tabular}{|c|c|c|}
\hline Specimen & $\begin{array}{c}\text { Water content } \\
\text { (wc) }\end{array}$ & Porosity \\
\hline Foam cement paste & 0.272429949 & 0.361257599 \\
\hline Cement paste w/c 0.5 & 0.185981426 & 0.3212191 \\
\hline Cement paste w/c 0.45 & 0.121424333 & 0.227664052 \\
\hline Cement paste w/c 0.35 & 0.076550758 & 0.158052405 \\
\hline Cement paste w/c 0.3 & 0.065029492 & 0.128380961 \\
\hline
\end{tabular}

TABLE 2.

DATA OF RESULT POROSITY AND UPV TEST

\begin{tabular}{ccc}
\hline \hline Specimen & Porosity & $\begin{array}{c}\text { UPV } \\
(\mathbf{K m} / \text { second })\end{array}$ \\
\hline Foam cement paste & 0.3612576 & 2.60 \\
Cement paste w/c 0.5 & 0.3212191 & 2.58 \\
Cement paste w/c 0.45 & 0.2276641 & 2.70 \\
Cement paste w/c 0.35 & 0.1580524 & 3.56 \\
Cement paste w/c 0.3 & 0.128381 & 3.67 \\
\hline \hline
\end{tabular}

